\title{
The Boys of Summer: Gay Sex Tourism in Rio de Janeiro
}

\section{Diego Santos Vieira de Jesus}

ESPM-Rio, Rio de Janeiro, Brazil

Email: dvieira@espm.br

How to cite this paper: de Jesus, D. S. V. (2020). The Boys of Summer: Gay Sex Tourism in Rio de Janeiro. Advances in Anthropology, 10, 125-146.

https://doi.org/10.4236/aa.2020.102008

Received: April 8, 2020

Accepted: May 9, 2020

Published: May 12, 2020

Copyright $\odot 2020$ by author(s) and Scientific Research Publishing Inc. This work is licensed under the Creative Commons Attribution International License (CC BY 4.0).

http://creativecommons.org/licenses/by/4.0/

\begin{abstract}
The aim of the article is to analyze the motivation of a group of Rio de Janeiro's men to engage in gay sex tourism, as well as the reasons for a group of Brazilian and foreign male tourists to search for sex with other men in the city. Following mainly Carrier-Moisan (2015), McKercher and Bauer (2003) and Mendoza (2013,2014), I argue that sex encounters between local men and gay tourists may involve money and perspectives of a better life for local men, especially sex workers, as well as the pleasure of the tourists. The results indicate that gay sex tourism in Rio de Janeiro also involves the negotiation and redefinition of values, stereotypes and expectations, which do not always include money. The study concludes that gay sex tourism in Rio de Janeiro may bring different types of personal involvement among the parts.
\end{abstract}

\section{Keywords}

Gay Tourism, Sex Tourism, Identity Tourism, Rio de Janeiro, Brazil

\section{Introduction}

Despite the heteronormative discourses and hostility towards homosexuals in many societies around the world, gay tourism-a LGBT travel market niche, designed to cater to gay men's consumer needs-has been strengthened with the spread of LGBT rights from the mid-twentieth century, as well as the changes in the demographic composition and cultural ideologies, the increased educational levels, the establishment of LGBT non-governmental organisations to pressure conservative authorities and the political decisions to equalise the rights of heterosexuals and homosexuals in many countries, such as the authorization for LGBT marriage (Vorobjovas-Pinta \& Hardy, 2016). Although tourism studies have tended to base the research on a universalized, contained, rational, and 
self-knowing subject (Johnston, 2001) and actually been defined in the mainstream by a middle-class heterosexual white male perspective, there has been an emergence of studies dealing with sexuality and gender identity related to tourism, including gay tourism (Mendoza, 2013). It has motivated numerous studies from the late 1980s, which focused mainly on the earnings, expenditure and travel arrangements of these travellers and often seemed to conceive that the market is homogeneous. The recognition of heterosexuality of public spaces made some authors to essentialize gay identity as a singular and static subjectivity, including in tourism studies (Johnston, 2001). Despite the heterogeneity of motivations of gay tourism, the need for safety, the comfort to be with like-minded people and the need to escape from heterosexism are usually indicated in the first studies as key influences on the tourists' choice, who still face discrimination, especially when they do not conform to expected standards of behaviour regarding stable relationships and gainful employment (Pritchard et al., 2000).

\subsection{An Introduction to Gay Tourism}

More recent research shows that the aspects of gay tourism may vary depending on locality, culture, political decisions or religion. Some African, Asian, Caribbean and Pacific countries, for example, deny the right to the freedom of expression for LGBT people, oppress and persecute homosexuals (Vorobjovas-Pinta \& Hardy, 2016). Authors such as Waitt \& Markwell (2006) indicate that a neo-colonial rhetoric of tourism as a universalizing force is accepted within the binary logic of tourist/host, which conceptualizes the gay tourist as part of a Western violation of some non-Western cultures, conceived as homosexual paradises for Western white gay men. Such representations rely upon fixed ideas about the Western and non-Western societies, sexual constraints and freedoms. It is possible to say that, when attention is given to the embodied individual in the gay tourism processes, local variations in the structure and style can be found, which reflect different patterns of social class and cultural differences in the construction and embodiment of homosexual subjectivities. In the light of these subjectivities, gay tourism destinations as leisure spaces of individual embodied performance are envisaged as fluid, personal, and improvisational sites of negotiation with local knowledge (Waitt \& Markwell, 2006).

Hospitality is related to the participation of service-oriented workers in tourism, which transform the place into a welcoming space for travel (Collins, 2007). Based on this idea, recent research on gay tourism paid substantial attention to the relation of this type of tourism and place-related identities and indicated, for example, that leisure activities in areas with a substantial offer of gay-oriented businesses usually enable gay men to enjoy freedom, which strengthens a common gay identity among tourists, who can experiment with their sexuality beyond rigid sexual identities. The use of public areas by LGBT people in oppressive contexts may enable processes of reterritorialization and the visibility of subcultures resistant to heteronormativity (Mendoza, 2013). However, gay tour- 
ism research also seemed to conceive that gay men are often high spending travellers, with more disposable income and formal education and less family-oriented concerns than their heterosexual counterparts. The gay tourists have also been categorized as "trendsetters" and "hedonists", who search for gay social life, culture, sights, comfort and relaxation, have the desire to distance from routines and aim to express their sexuality in safe environments, especially closeted gay men who search for the opportunity to get free from societal constraints. Although the demographic, motivational and behavioural aspects of gay travellers may be more complex and must not be taken for granted, the opportunity for sex with other men-the local ones and other tourists-has been frequently indicated by gay men as one of the most relevant motivations to travel (Vorobjovas-Pinta \& Hardy, 2016), besides the needs for escape, a sense of belonging and safety and the opportunity to live one's identity more freely in a largely heterosexual world, in which their sexuality is ridiculed or hidden (Pritchard et al., 2000).

\subsection{An Introduction to Sex Tourism}

Sex tourism can be defined as the travel for which one of the most important motivations is the engagement in commercial or non-commercial sexual relationships. It means that sex tourism involves more than the monetary exchange, frequently associated with prostitution (Oppermann, 1999). These sexual relationships may not be limited to simple commercial transactions, because they can encompass emotional involvement, romances, long-term relationships and other non-paid activities (Mendoza, 2013). The search for sex also motivates heterosexual people to travel, but, in the case of many gay men, it is frequently connected to the opportunity to be free in non-judgmental spaces, where they can have the sense of belonging to a specific particular community in the light of the predominance of heteronormative spaces in private and public destinations. Many gay-friendly travel destinations-usually urban agglomerations and beach areas-allow like-minded people to share common interests, including the ones related to sex, and may change through time, including leisure places with more freedom and self-recognition. Nevertheless, the supposedly complementary relationship between sexuality and space may have negative connotations even for gay travellers, because it implies the association of gay tourism with the desires of specific and stereotyped groups of gay men and is usually connected to illegal activities, such as child exploration and abuse and drug-dealing (Vorobjovas-Pinta \& Hardy, 2016). When sex tourism involves prostitution, it may exist as a fuzzy legal activity, which is largely proscribed in many countries, but keeps existing within a legal and social framework of constraint and limited tolerance. The tourism literature has tended to perceive sex tourism as a deviance, but it can be argued that this type of tourism also involves satisfaction of needs of social companionship, fantasy fulfillment, the search for something new and opportunities for relaxation, which makes sex tourism consistent with the 
norms of tourism. However, as it also involves liminal activities outside the main norms of behaviour, it brings a debate on what constitutes the socially acceptable behaviours (Ryan \& Kinder, 1996).

\subsection{An Introduction to Gay Sex Tourism in Rio de Janeiro}

Present-day Brazil-one of the world's most relevant destinations for sex tourism-still features a high disparity between rich and poor. Throughout Brazil's history, changes in political economy have affected subjectivities in the male sex trade (Mitchell, 2010). In the light of the present crisis the country faces because of the economic slowdown after a period of intense growth and the political chaos motivated by denunciations of corruption, the fall in the quality of life of many citizens made many men turn to sex work, including sex tourism for money. The case of Rio de Janeiro-as some other cities in Brazil and other countries-serves as a sex tourism destination and many people have an uneasy relationship to sex tourism, because this type of tourism is connected to racialized, gendered, and sexualized notions of citizens' roles in the transnational tourism industry. Tourism plans can be defined upon an exoticized and sexualized labour force which is understood, in economic and symbolic terms, in the position to serve outsiders. This reinforces the erotic subjectivity of same-sex desiring men in the developing world (Collins, 2007). Some nations such as Brazil-Thailand and Russia are also examples-show concern with the growth of sex tourism in the light of the social uncertainty associated with globalization and the degradation of economic conditions, which have sustained the growth of prostitution and commercial sex premises. However, it is important to say that, if only economic motivations for sex tourism are considered, one may not consider that capitalism seems to reduce human interactions to simple commodities and marginalizes the subjectivity of people involved in sex tourism, the social conditions that result in its growth, and the exploitation and liberating possibilities that surround sex tourism (Waitt \& Markwell, 2006), including in cities of the developing world, such as Rio de Janeiro.

Rio de Janeiro is universally known because of its natural beauties, samba and festive occasions, such as Carnival. The city is usually seen from the perspective of the "paradise", by the lenses of the tourist. The "tourist gaze" indicates that the place is fundamental when corporeal and virtual or imagined displacement or mobilities are considered. In tourism, the choice of destination is characterized by the difference from the daily and mundane experiences and constructed by social practices, culturally marked by the historical context (Urry, 2007). In Rio's image, as in Brazilian culture in general, the polymorphous character of sexual pleasures is hardly limited, although primary emphasis seems to have been given to heterosexuality as the only legitimate form of sexual expression and other sexual practices-such as homosexuality-have been typically defined in negative terms of condemned conducts which have served to define and legitimize what is normal or conventional. Within the erotic frame of reference, the 
bodies in the city-especially the black female bodies-are constructed as objects of desire and sources of pleasure. However, especially in the context of the diffusion and communication of tourism in Rio, this sexualization gradually extended to many different bodies, including the men's bodies. They may also be erotic bodies, characterized by beauty and sensuality, full of erotic potential (Parker, 2009). Known as "The Marvellous City", Rio de Janeiro was recently brought into the spotlight as a consequence of the 2016 Olympic Games, when a new image of "The Olympic City" was globally publicized (Nogueira \& Di Cola, 2018). However, it did not eliminate the previous sexualized images of the city, including those connected to the sexualization of the gay male body.

The aim of the article is to analyse the motivation of a group of Rio de Janeiro's men to engage in gay sex tourism, as well as the reasons for a group of Brazilian and foreign male tourists to search for sex with other men in the city. Following mainly Carrier-Moisan (2015), McKercher and Bauer (2003) and Mendoza $(2013,2014)$, I argue that sex encounters between local men and gay tourists may involve money and perspectives of a better life for local men, especially sex workers, as well as the pleasure of the tourists. However, gay sex tourism in Rio de Janeiro also involves the negotiation and redefinition of values, stereotypes and expectations, which do not always include money, but bring different types of personal involvement among the parts.

\section{Theoretical Framework}

\subsection{Gay Tourism}

Some authors identify that there is a link between gay men and travel and see tourism as an important aspect of gay identity and lifestyle (Hughes, 1997; Herrera \& Scott, 2005), which implies that gay men travel in the search for spaces where they can socialize with other gay men, as well as avoid social constraints and symbolic and physical violence (Monterrubio et al., 2007). Travel also creates opportunities to explore gay cultures (Cox, 2001). Although gay men look for relaxation, escape and self fulfilment as heterosexual tourists also do, the gay-friendliness of the destination and the existence of a gay tourism industry are significant factors for the destination choice of gay tourists, because it may provide these men with the opportunity to be themselves. Sex also appears to be a relevant factor in the gay travel (Monterrubio, 2009), as it will be developed below.

As heteronormativity underpinned many gay men's search for a home, the social and cultural lives of the homosexual men constituted by Western thought have often retreated underground (Johnston, 2001; Waitt \& Markwell, 2006). In the light of the heterosexual construction of public space, gay people have been accepted as "virtually normal" at a high cost: the loss of difference, which was welcomed by some people as an escape from the ghetto, but the respect for sexual differences seemed only to apply to those who do not threaten society with more explicit versions of gay identity. It is possible to say that gains for homo- 
sexual men have neither been uniformly nor universally distributed, which can be seen in the case of homosexuals who are only "allowed to be gay" in limited spaces and places. The dynamics of heterosexual power reveals the desire to control tourism behavior, so that tourism sites and processes are far from immune from the constraints of heteronormativity. Sexuality may impact the leisure worlds, because these destinations may provide opportunities to escape the heterosexual oppression and respect and openly celebrate homosexuality (Pritchard et al., 2000). Many gay men live in areas dominated by heterosexism, so leisure activities and holidays are significant for them, because they provide a significant opportunity for constructing their sexual identity (Hughes, 1997; Monterrubio, 2009).

The gay tourism industry started to be defined under the umbrella of new international and national LGBT tourist organizations, which include travel agents, marketing and distribution firms, accommodation providers, tour wholesalers and hospitality. This industry has been fundamental in producing and circulating images of homelands about places gay men have never visited, as if they were homes away from the place of residence. In the development of gay tourism, most gay men still adopt a conventional masculine identity, which shows that they are still oppressed by heterosexism. However, gay travel cultures continue to grow from social processes in which gay men seek counterhegemonic places where they can be themselves by the performativity of their gender and sexual identities and, for some men, scape from the straitjacketed "closet". Nevertheless, it is important to say that not all gay men can afford to travel and have a lifestyle characterized by leisure and pleasure-seeking in the light of their socioeconomic status. Some level of cultural capital remains necessary to negotiate in the counterhegemonic spaces in many tourist destinations, such as parties, Pride parades, gay resorts, nightclubs and bars, in a quest for individual and collective identities (Waitt \& Markwell, 2006; Silva et al., 2018).

The phenomenal growth of gay tourism from the 1990s on can be seen in the rising number of available accommodation properties, the acceptance of gay tourism by many national and local governments, the use of internet by gay tourism agents to promote destinations and sell services and the interest gay tourism brought to mainstream media (Waitt \& Markwell, 2006). In the light of these opportunities, the hospitality to gay tourists usually accommodates some efforts to change the face of tourism in some cities and countries in the context of global restructuring of gay travel with neoliberal economic and cultural transformations, which involve the division of service labor and leisure built upon the mobility of workers and consumers, the global integration of tourism economies and the rise of identity markets in the travel sector. However, it is important to say that gay hospitality may often evade state control, especially when it involves sex work, once hospitality is, on its surface, companionship and guide work. Gay tourism can go from the overt commodification of local hospitality to the less explicitly commodified understanding of relations between local 
citizens and travelers as desirable companionship and friendship, as well as the emotional care of "outsiders". The hospitality involved in gay tourism helps build the identity of the place as a gay destination and justifies formal and informal laborers' connection to urban place (Collins, 2007). According to Collins (2007), places, people, and experiences could be seen as elements of "consumerism" in gay travel, which might reinforce inequalities between rich and poor gay men or function as an engine for social change that transcends and determines male sex work in some destinations. Formal and informal gay tourism activities can produce hybrid identities, as well as resistances in the transnational relations of gay travel.

Gay tourism may also vary in the level of its formal institutionalization. Some places have organized gay tours, bars, restaurants, clubs, bathhouses, massage parlors and resorts and people who have the cultural knowledge that the traveler does not have and show their concern over the tourist enjoyment, eating, sleeping and safety. However, others only count on informal relations, which usually involve tourists, sex workers and hosts and foster social and sexual exchanges (Collins, 2007). In some destinations where there is no full acceptance of homosexuality, gay travelers are expected to express their sexuality in very specific places, such as bars, clubs, saunas and gay-exclusive hotels, hostels and beaches. The concentration of physical gay spaces brought the opportunity to socialize with other gay men and focus on their common interests. With the development of social media and technology, some travelers-especially younger men-use technology-based platforms such as smartphone apps to interact with other gay men in the destination, the local gay men or other gay tourists. The virtual spaces created by these technologies may create other interesting destinations for gay men, especially those who are looking for a relationship or sex (Vorobjovas-Pinta \& Hardy, 2016; Brito et al., 2019). However, it is important to highlight that, in some destinations, given the heterosexual nature of public space, gay destinations, hotels and resorts may look like safe places, but they may also ghettoize gay men and heighten their vulnerability. Besides, not all gays seem to be conscious of being exploited by the tourism industry in the light of the spending power of their "pink money". The transactions may also be heterosexualized and open spaces for mainstream tourism operators to charge premium prices for non-heterosexual men (Pritchard et al., 2000). In some countries, history, legislation, culture and religion may have a negative impact on the treatment of gay tourists. This treatment comes from the power of mainstream tourism industries, in collaboration with local elites, to marginalize gay tourists through the heterosexualization of some destinations and an emphasis on gay tourists as if they were motivated exclusively by sexual contact (Want, 2002).

Many gay hosts do not define hospitality as work, which may collapse the separation between entertainment and work, companionship and service, love and sex and show the diversity of gay men, who do not necessarily share a common understanding of companionship and commercial transactions. In some cases, 
hosts understand that sex may be a part of hospitality and see sexual relations as embedded within the hosting experience. However, critics indicate that tourists who live in richer areas of the world may see boundless sexual opportunities in their travel destinations, which can stimulate illegal activities connected to gay sex tourism (Collins, 2007).

In the light of this discussion it is possible to indicate that the subjectivity of the gay tourist is an ongoing relational process defined by the movement of his body through material places and structures and the encounters with other people-local citizens and other tourists. This process may reflect the inscription of power and ideology on the bodies in tourist places or create opportunities to redefine identities. Tourism destinations which can be conceptualized as spaces of visibility rely upon discursive meanings reproduced and circulated by the gay tourism industry, as well as movies and experiences of other tourists shared on the internet, and their meaning as imagined tourist geographies may be reinforced or challenged by the mental and sensuous processes of the tourist in limited spaces-such as resorts, beaches and cruising areas and structures that anime these spaces, such as cruises, stadiums and dancehalls. The body of the gay tourist may transform the space though its presence in the destinations. At the same time, the layout of leisure spaces and the design of structures can delimit how the performances of gay identity occur in these destinations. The place is fluid rather than fixed and produced by multiple social, political and economic relations, including straight and LGBT people. The processes of pitching, marketing and scripting the meaning of gay tourism destinations are complex in the light of the interaction of power relations that operate across many spatial scales, from the individual body to the global scale. As result of these processes, there may be multiple and even conflicting understandings of gay tourist destinations. These destinations also matter because tourism can be driven by some special events and festivals-such as Pride parades and Mardi Gras-instead of simply by the sights. The connection between the topic of this section-gay tourism-and sex tourism-the topic of the next section-can be illustrated by the involvement of the whole body in attaining pleasure, which is implicated at a greater level through participation in the events than in conventional sightseeing. For example, the "perverscapes" reconfigure nonhegemonic sexualities, as it can be seen in the performances of gayness at festivals for the people who participate and are spectators of these events (Waitt \& Markwell, 2006).

\subsection{Sex Tourism}

The consumption of sexual items and experiences-which suggests, promises, and/or stimulates sex-occurs frequently during leisure time and can be enhanced through the depiction of a leisure destination as a sexualized environment through sexual innuendo, erotic images, and the sexualized body of locals. This incorporates the direct consumption and pursuit of sexual encounters to the utilization of bars and nightclubs as pick-up joints for the pursuit of casual 
sexual encounters, romance and love. The beach can be used in multiple sexualized ways, including voyeuristic ones, as well as public conveniences such as parks, utilized for casual sexual encounters. The sexual nature of tourism experiences is open to negotiation as the behaviors of tourists can also influence the sexual images associated with determined environments (Carr \& Poria, 2010; McKercher \& Bauer, 2003).

Sex tourism is usually understood by the blurring of boundaries between hospitality and sexualized labor, based on economic exchange and/or exploitation. It is often portraited as a result of fantasies about exotic places with hospitable people by travelers, who expect intimate services in tourism. Some perspectives on sex tourism research indicate that sexual laborers may claim "worker" identities and confront exploitation in the industry. The identification of sex work as work may bring its politization, once sexual laborers can share a common struggle against economic and sexual oppression, including heteronormative controls. However, while a political economy to sex work operates, there may be a libidinal and emotional economy at work, which involves the emotional dimensions to sexual work, including the management of sexual performances by sex workers not to fall in love with their clients (Collins, 2007). Sex tourism is frequently reduced to commercial sexual relations, but it is a simplification, which excludes many other complex cases, processes and settings, by which individuals choose to seek sexual gratification. It means that sex tourism is not a synonym for prostitution, even though prostitution may be involved in sex tourism. Besides many tourists who have sex with local people do not travel for that specific purpose. The "situational sex tourists" are a group formed, for example, by many business and conference tourists who have sex with prostitutes or other local people while traveling. There are also some tourists who find sexual gratification as part of the travel experience without resorting to prostitutes. The "virtual sex tourist" has many websites and apps to choose from with a vast array of different people in the search in cyberspace (Oppermann, 1999).

Some of the first studies on sex tourism research have concentrated on the extent of sexual activity and the degree of risk of sexual infections of travelers (Clift \& Forrest, 1999). Sex tourism cannot be fully understood as a synonym for sex work destined to tourists. Many local people involved in sex with tourists do so because they understand that hospitality may be not only an expression of local identities, but also a celebration of desire. Instead of seeing sexuality as a commodity, some people engaged in sex tourism understand their relations with travelers as a connection that requires some type of emotional bond, which does not necessarily involve the negotiation of money for sex. The sex involved in hospitality challenges the perspective which conceives sex work with tourists as the same as sex tourism (Collins, 2007). Investigations on sex tourism focused mainly in the tourist perspective, especially his/her opinions and experiences. The tourists' motivation may include "the search for the racialized other", sex techniques and even romance. The positions of sex workers are rarely taken into 
consideration. When they are considered, the emphasis has been mainly on the negative sides of sex tourism, such as child prostitution and the transmission of sexual diseases (Mendoza, 2013, 2014).

Gay tourists usually say that motivations to travel include the opportunities to socialize with other gay men and experience gay culture and venues, but sexual encounters are also important motivating factors for many of them. The destinations may bring opportunities for sex that many gay tourists do not have at home. It is possible to say that tourism may offer a liminal environment away from the obstacles at home, a possibility to reduce inhibitions and increased opportunities for sex. The sexual behavior of the gay tourist at his destination can vary from more subtle socialization and cruising to the open engagement in casual same-sex activity, such as public lone and mutual masturbation, oral sex, anal penetration, voyeurism and gay gang-bangs, especially in places such as nude beaches-in some specific spots, when the place is also frequented by heterosexual people, or all along the beach-and cruises. Some of these activities may occur in daylight and be observed by local people and other tourists, who may be gay or not and engage in these activities or not. The experience of gay tourism may involve commercial relations between locals and tourists and drug-dealing. In some places, there are even allegations of sex trafficking and the commercial sexual exploitation of children, which, for many local communities, blurred the lines between pedophilia and homosexuality when discussing sex tourism and the sexual abuse of children was the result of the actions of "homosexual perverts" (Miller, 2011; Monterrubio et al., 2007). Taken as neo-colonial force, sex tourism can also be understood as a market for sex experiences which is served by the local culture of the destination communities and bring changes in response to the demands of tourists that bear little resemblance to the pre-tourism culture. In the case of gay sex tourism, it seems to commodify aspects of gay cultural life, including sex, and create outcomes of conformity and stereotyping (Waitt \& Markwell, 2006). Sex tourism may include the ways in which historical patterns of racism and colonial power are reproduced and maintained and tourists not only just conquer and penetrate exotic places, but also the bodies of local people (Rivers-Moore, 2011).

However, some gay sex tourism studies emphasized issued from the use of large infrastructure of bars, saunas and escort services in huge urban centers by gay tourists to less commercial perspectives, which takes into account the definition of interchangeable, disputed and fractured sexual identities and opens possibilities for multiple emotions, experiences and social practices brought by different kinds of personal involvements on the parts involved, such as gay travelers and local men or client and sex workers, which include values and expectations before, during and after sex (Mendoza, 2013). The possibilities for these interactions may be also created by gay press, which usually suggests that sex can be an important motivation for some gay travelers. Books and guides may bring sexually explicit photos and ads which promote and recommend places where 
both casual and commercial sexual encounters may be developed. It may also bring guidebooks that provide accommodation, food and entertainment information for gay travelers, as well as information about sex clubs and public sex environments in travel destinations. The internet also has made detailed information about casual and commercial sex more available for gay men through websites and social networks (Monterrubio, 2009).

Nevertheless, it is important to notice that the image brought by the gay press and the internet may be one of "staged authenticity" in tourist settings. It means that the quest for authentic experiences through tourism is connected to the tourist's desire to have genuine experiences rather than staged expressions of intimacy. But the performative dimensions of tourist destinations may offer sometimes artificial and constructed forms of intimacy. The development of gay identity in some Western countries seems to be connected to the emergence of global urban capitalism, which requires the consumption of multiple homoerotic experiences. Sex tourism might work as a vehicle through which some contemporary gay men gain access to sexual experiences which some of them consider to be "authentic", but may be a fake expression of desire by some local men who do this for money (Padilla, 2007). As Carrier-Moisan (2015) indicates for racialized women in Brazil, local men-especially sex workers-can also make strategic use of their hypersexualized bodies in sex tourism. They can establish both their hypersexuality and respectability through processes of distinction in which some may show the potential for mobility, migration, and marriage that comes with sex with tourists and others may repudiate the figure of the "vulgar" or "greedy" prostitute and assume a formal macho figure to signal respectability. These men can "put their masculinity to work", a type of embodied capital and one of the few resources they have.

Some images of the Brazilian men were reiterated by gay press and the internet and assimilated noncritically by tourists, who come to Rio de Janeiro looking for men who seem to be representatives of indomitable sex, always ready to quench their endless sexual hunger (Reimóndez, 2007). In the late 1990s, hustling adjusted to the beginnings of a global boom in gay tourism, a time when many men were coming out also in terms of their purchasing power. While in the 1980s hustlers had mainly to work in train stations and street corners in Rio, selling sex mainly to effeminate homosexuals and closeted married men, male prostitutes in Rio in the 1990s focused on several public cruising areas. By 2000, these areas were increasingly moving indoors and catering to a growing number of gay tourists. As gay tourism started to consolidate as a niche industry on a global scale, gay tourists in Brazil came to be lucrative clients. The tourists willing to pay for sexual services could have relative safety in the social environment of bathhouses, but hustling still occurs outside, especially on beaches and in parks (Mitchell, 2010).

However, it is important to say that the reality of sex tourism in Brazil may be more complex and diversified. First, sex tourism is not a synonym for sex labor. 
Second, sex workers and men who have nonpaid sex with tourists cannot be understood simply as "victims of global capital". To see them as victims elides the dynamic relationship among them, the tourists, and the sexual ideology in which peripheral bodies are interpellated as always accessible sites of pleasure and danger to be exploited (Allen, 2007). Some local male sex workers, for example, sometimes negotiate stigmas by attributing it to others-such as transvestites ("travestis"), usually labelled as effeminate ("men who dress like women"), excessively promiscuous and responsible for spreading sexually transmitted diseases-and establishing themselves as respectable for their masculinity, commonly connected to responsibility, commitment, strength and other aspects valued by tourists (Blanchette \& Da Silva, 2011). The self-making processes of local men involved in paid and nonpaid sex with tourists are also negotiation processes of their own status within local understandings of respectability, which can be seen as attractive by many tourists who want to have not only sexual, but also affective relations with locals. The imagined Brazilian men-especially those who live in cities that have beaches-are often endowed with a tropical sexuality characterized by sensuality, frequent desire, strength and masculine aspects in behavior, attitudes and their own bodies-such as suntanned skin and athletic appeal, which are usually objectified by gay tourists as the Brazilian woman's body is for heterosexual tourists. Especially when their skin is darker, this image is reinforced by the colonial representations of both African and indigenous men, which eventually made their way into a national ideology celebrating racial mixture. The sensual and dark-skinned body was displayed nationally and internationally, and its sensuality might extend potentially to all Brazilian men involved in sex tourism (Carrier-Moisan, 2015).

Some locals try to present themselves in gay sex tourism as loveable and marriageable men to mitigate stigmas related to Brazilian men and especially the typical sex worker, while they still play their hypersexuality, which can be very attractive for national and international male tourists, conceived by these local men as a possible way to access a better life, and make these local men use forms of their embodied capital in projects of social, economic and spatial mobility (Carrier-Moisan, 2015). The aspirations of many Brazilian men who exchange sex for money with gay-identified male sex tourists from North America and Western Europe are connected to the discovery of routes available to them for consumer consumption and possible migration (Mitchell, 2010). However, not all local men involved in sex tourism have these projects or have sex with tourists for money. They are looking for casual sex with different people or even romance, with no commoditization of their relations with tourists (Mendoza, 2013).

On the other hand, some local men involved in gay sex tourism in Brazil-especially male sex-workers who identify themselves as "straight"-sometimes may not fear the stigma, but try to justify their participation in sex tourism because of their "material necessity" in the light of frequent economic crises Brazil 
faces and avoid their association with feminine aspects and the transvestites (Perlongher, 2008). Some of them do not see problems when their masculinity is deployed associated with the figure of the greedy prostitute and overcome or try not to be bothered by the stigma of sex work in the light of their financial contributions to the family, which fits with predominant ideas of men as providers (Padilla, 2007). In their relations with tourists-seen as clients, they try to preserve their emotional distance or develop a homoerotic socialization that opens to many men an opportunity to create some type of camaraderie with other men (which can be seen as equally "machos" or "brothers"), in a context in which the superiority of manliness and hegemonic masculinity are recognized, but it does not exclude the possibility of sexual involvement with other men. When they adopt this, many men feel they are more protected from the humiliation and bad treatments women and transvestites usually face (Miskolci, 2013).

Some gay tourists-especially the foreign ones-fetishized wielding economic advantage over straight-identified macho men in the global South. They sometimes seemed to presume that every waiter, vender or passerby would be sexually available, even if it were necessary to pay the right price for sex. Nevertheless, most tourists treated their sex tourist companions respectfully and some even fell in love with them, showing their willingness to rescue the sex workers from prostitution, pay for their family expenses, take them to shopping sprees and nice restaurants or even help them arrange visas to travel. Although some tourists get fascinated by the Brazilian men's virtuous performances of Latin machismo, they persisted in their beliefs that most local men were really gay "deep down", which motivated misunderstandings with local men who were not interested in emotional connections with them, not even their money. Some tourist bring the preconceived idea-reinforced by gay pornography, fiction and magazines-that Latin men who have relations with women can feel free to have sex with another man without compromising their masculinity as long as they are "tops", not "bottoms". Even though many Latin men assume this idea as true, there are clear exceptions in areas with a more patriarchal and homophobic formation (Mitchell, 2011).

\section{Methodology}

The research design was composed of the research question and the theoretical framework indicated above, as well as the methods to collect and interpret data, presented at this section. A qualitative approach is used in this article to have detailed information about behaviours, concerns and attitudes of tourists and local men involved in gay sex tourism. Regarding the local population, I adopted the same line of investigation of Mendoza (2013), gathering information about places and times that gay sex with tourists occurred, including a mapping of the information available on the internet. After the initial bibliographic study on gay tourism and sex tourism, the following step of the research process was a participant observation from January to November 2019. It was useful in beaches, bars 
and nightclubs in the city of Rio de Janeiro to detect how sex encounters were negotiated, as well as the general dynamics of interactions between negotiating parties. When the negotiation happened through the internet (in gay apps or via WhatsApp), I companied the process of negotiation from the point of view of both tourists and local men. Data collection also included observational work and information from informal conversations in the field.

Semi-structured interviews were also implemented with 10 tourists (five from other Brazilian locations and five foreigners from the United States and European countries) and 10 local men. All the men considered were informed about my status as a researcher and the purposes of the investigation, as well as the anonymity of their responses. They were all men interested in having sex with other men, not transvestites nor transgender people. I completed taped in-depth interviews (ranging from 20 to 75 minutes) and compiled informal talks in the field. The interviews were formulated taking into consideration the sociodemographic profile of the interviewed people, their motivation for the involvement in sex tourism, the interaction with the other part, the sexual practices and identities, the risks involved and plans. The subjects considered included two full-time and six part-time sex workers, as well as occasional and frequent sex tourists. They all attended clients who found their ads at internet websites or their profiles in apps. Among the local men in Rio, six were born in the city, while two came from other cities in the state of Rio de Janeiro (Nova Iguaçu e Duque de Caxias) and the others from other Brazilian states (São Paulo and Bahia). Even though most local men (8) considered themselves "gay", one sees himself as "heterosexual" - he is married and has a child, and his wife knows about his job-and one considers himself "bisexual". Seven tourists also consider themselves to be gay, but the others say they have heterosexual lives. One is even married to a woman. Ages ranged from 18 to 40 among local men and from 30 to 60 among tourists. The results were qualitatively analysed in the light of the theoretical framework. It is important to highlight that it was not my intention that these interviewees should be representative. The aim is to have a deeper insight into the observed activities and the characteristics of the people involved, similarly to the methodological perspective adopted by Monterrubio et al. (2007).

\section{Results}

\subsection{The Local Men}

Most local men engage in work in sex tourism because of money, which represent a better choice between other possible jobs in Rio or even the salvation in times of harsh unemployment in Brazil. Six of the ten local men interviewed were part-time sex workers. Their other work included professions such as model, actor, hairstylist, waiter, hotel receptionist and event promoter. One of the two full-time sex workers said he did not like to engage in sexual activities with tourists, but he needed to. "I need to eat, I have a wife who needs me, a child 
who needs a father. I don't fuck these gringos because I like it. I am not like these faggots who give their asses to whoever they want. I do it for the money. My wife doesn't like it either, especially because sometimes I arrive home late at night, but what are we going to do? I am the man at our home. I have to provide things for my family". The other full-time sex worker said that "these are hard times even to work in some activity like a waiter or an Uber driver. I ended up here. It is also a hard life, you know? And it is not as easy to make money as people think. But at least it gives me some opportunities to be in nice places I can't afford by myself like classy restaurants and hotels, meet nice people, have more cash than doing other thing. They [the tourists] also buy me stuff like this iPhone, nice clothes, shoes... I would like to work with something else, but I need to be here if I want to have all these things". A part-time sex worker also said that "to overcome the crisis, we have to do everything. I work as a waiter in the afternoon, but, in the morning and at night, I meet the clients who send messages through my WhatsApp. That's the way life goes. I would like to have something better, but what can I do?”

In countries with a strong patriarchal tradition, men who penetrate other men usually do not see themselves as gays, so that they have more chances not to be socially stigmatized, as is the case of "bottoms" in sexual relations (Hodge, 2001; Mendoza, 2013). However, five gay local men-three were part-time sex workers and the other two were not sex workers-say they also have sex with tourists for pleasure. "They look so beautiful... Blue eyes, white skin, hairy... Some look like princes", one of the local men who was not a sex worker said. "Usually they are very good in bed. They say I'm hot and I like to hear this shit. I can't deny”, one part-time sex worker said.

The other part-time sex workers said they tried to contrast them with other prostitutes. They presented themselves for the clients as respectable men or did not have any sexually transmitted diseases. All the interviewed men declared they always used condoms in their sexual relations with tourists, showed knowledge about safe sex practices and engaged in HIV testing periodically. "I tell them [the tourists] I have the dream of having my own business. I like what I do, I also do it for pleasure, but I'm not like these guys who think they will live from sex forever. Maybe my clients can help me make my dream come true giving me money or even marrying me and taking me to their home. And they know I take care of myself: I always use condom, tell them I engage in HIV testing once a month. I'm not an irresponsible boy. I'm a real man". The other said "I give them [the tourists] a different service, also because I like when they are handsome guys and want to get impressed by a Brazilian macho. I am handsome, I work out every day, I am clean and healthy... I am not like those mosquitos full of diseases who work on the street or like these 'travecos' (transvestites), who are women with cocks... I'm a real man. They won't find someone like me so easily". The same man said that, when some tourists come to Brazil, they call him or send him messages through WhatsApp. He says he has a lot of foreign clients 
and this happens not only because he works out a lot and is very sociable, but also because he started to learn English to interact with them. "My language skills were very useful to me, because I can say naughty things they like to hear in bed in English and in Portuguese. They love to hear me feeling pleasure in their language and in mine".

However, the other five local men said that they only had sex with tourists for necessity. "If the guy pays, I go with him. If he doesn't, there is no way", one of the part-time sex workers said. One of the full-time sex workers criticizes the men who "have sex for free": "They are stupid and the worst thing is that some clients who go out with them think we should do the same. Once I almost hit an American's face, because he thought my body was for free because the others had sex with him and he did not have to pay. I hate these fucking bitches". The other full-time sex worker considered himself as a "normal guy" and stressed that he was very selective regarding his clients, which is something also considered by all part-time sex workers and the local men who have sex with tourists. "I want an interesting, handsome guy... I don't want trash. We have a lot of trashy men here in Rio! So, if I go out with someone I find on the beach or on Grindr, he has to be the one", said one man who has nonpaid sex with tourists for pleasure.

\subsection{The Tourists}

Some tourists say that affection and friendship are relevant for them, which suggests that sex tourism not only involve financial, but also emotional issues. This is more visible in older clients, who also search for company. For most local men who consider themselves to be sex workers, these older men are preferred, because they are believed to have more money to spend. "The older gays ("os velhos") are the better ones. Even though sometimes to have sex with them is nasty because they are dirty, they pay much better and sometimes even promise to marry you and take you to their country. A friend of mine is now living with his husband in Portugal. The guy is 25 years older than him and was his client", one part-time sex worker said. The two local men who were full-time sex workers said they avoided to develop more intimacy with the tourists, but the others said they tried to express more intimacy and sociability, even though sometimes it was a staged one. "I say I like them a lot, they give me a lot of pleasure, but that's a show. I feel like an actor in a porn movie. But when they like caress and say they need more affection and romance, I act like a soap opera star", one of them who also work as an actor said. However, some local men who did not consider themselves to be sex workers said they developed real feelings about the tourists. "I found Matt on Grindr while he was on vacation in a hotel in Ipanema [one of Rio's richer neighborhoods]. We met at Farme de Amoedo [a gay point in the Rio's Southern area] and became friends. We talk almost every day through WhatsApp. I want to marry him, but he is still married to a witch [laugh]. I guess I really love him", a 30-year-old local man said. 
Three Brazilian and two foreign gay men considered in the research were travelling alone or with one or two friends, who were also gay men seeking casual sex with other males. I asked a 37-year-old American tourist if he considered that Brazilian boys had something "different" from Americans and men of other nationalities he already had sex with. He said "They [Brazilian men] are always sun-tanned, their skin is great... And they are real man. They make you feel like you're their bitch. I love to be their bitch, but they still make me feel like a real man. It is a weird thing". A 30-year-old Dutch man who visits Brazil especially for sex said that "Brazilian boys treat me so well... Sometimes I see it's fake, but they try to be nice to me, even when I don't pay for sex. What is more interesting is that they say I am a nasty bitch during sex, but they act like gentlemen before and after sex. Some even call me "brother" ("irmão") or comrade ("camarada"). Some still call me "kid" ("lek", a Portuguese slang word that is a reduction of the word "moleque"). They are always very casual, informal... They are really beach boys, and that's why I love them". "They treat me well, they are sweet... They spend more time with me when I feel alone... How can't I love these boys? I know I will marry one of them someday", said a 49-year-old French tourist who frequently come to Brazil on his vacations. But a 37-year-old American told me that, in one of the many times he came to Rio on vacation, he tried to pay a waiter for sex. "He almost hit me in the face and said that I was detestable in the sight of God. I thought Brazilian men were very liberal, but they are not. I don't know if it is because of religion, because of this macho tradition or both. But I learned that you can only start this type of conversation about sex after the guy tells you he is really interested in sex. They are all very macho, and many hate gay men".

Sexual encounters at beach in the Southern and Western parts of the city were common among men from different parts of Rio Janeiro and Brazil, and even some foreign men are often involved. Older men-a 47 year-old Brazilian man and a 60 year-old American man-were looking for casual sex with younger men in bathhouses and beaches, including the nude beach of Abricó. "The thing I like the most in Abricó is the orgy ("putaria")", the 47-year-old Brazilian tourist from the state of São Paulo said. Usually behind the many rocks in this beach in the Western part of the city, men masturbate each other, have oral and anal sex or only look at others doing so. These encounters could also be observed behind the bushes at the Reserva beach at the same part of the town, which is not a nude beach, but men have different kinds of sexual activities on the forest next to the beach at daylight and night, as well as in the sand when the beach-which is also frequented by heterosexual people-is not so full of people. Two local men usually have sex with tourists in the area of Reserva beach. They find these men at apps such as Grindr and Scruff or cruising along the bicycle path. One of them sometimes charges tourists for oral and anal sex, especially foreign ones who stay in hotels at Barra da Tijuca, a middle and upper-class neighborhood next to the Reserva beach. 
Recreational drug use occurred between local men and gay tourists in some occasions, especially on the beaches and bathhouses. Two local men were also drug-dealers, and drugs such as cocaine also featured in the transactions about sex. "Rio is all about Carnival, sex and drugs", said a 37-year-old tourist from Porto Alegre, the capital of the state of Rio Grande do Sul, in Brazil. "Boys get high in Carnival blocs, nightclubs, the Pride... You can buy ecstasy, cocaine, special $\mathrm{K}$ [ketamine] with them directly or some dealer, who is always around. When you see these guys' perfect sweaty bodies, man... It is impossible to resist", said a 39-year-old Brazilian tourist from Belo Horizonte, the capital of Brazilian state of Minas Gerais. Some local men who sold drugs to tourists said that many common people saw them dealing with drugs and did not like it. "When we are on the beach, some people see and don't like. Once a woman even called the cops in Copacabana's beach when she saw me selling special K to a Spanish guy. But we have to take some special cares when we also sell drugs. In some places, such as the nightclubs and isolated beaches in the Western zone, it is easier, because there are not many cops around", a part-time sex worker who was also a hotel receptionist said.

\section{Discussion and Analysis}

In line with the argument indicated by Mendoza (2013), the search of "otherness" in sex tourism is based in Latin stereotypes of North-Atlantic and Eurocentric gay images, which are usually seen in gay guidebooks, travel brochures and websites who represent Brazilian men as "the exotic other", which is also desired because of their male attitude. Although one of the local men who considered himself as heterosexual hated to participate in sex tourism, the others either liked to do what they did or considered that male sex services were acceptable within the limits of their perceived manhood. Most sex workers tried to separate their image from the notions of disease, degeneracy and dirtiness, as Carrier-Moisan (2015) argues. As the author also indicates in her discussion about women's prostitution in Brazil, the main reason cited by men for entering sex tourism was money. It is also evident that these men tried to distinguish themselves as more respectable by insisting they were not there because they were after luxury, but because of necessity and the lack of better opportunities in the light of the economic crisis. The discourse on necessity was a way to distinguish themselves from the figure of the greedy prostitute, who seemed to have an easy lifestyle. Also in line with Carrier-Moisan's (2015) argument, some men also emphasized the better financial gain provided by paid sex with tourists in contrast to available opportunities in the service sector, even when they also work in some other activity. Their "material necessity" in the light of frequent economic crises is accompanied by the necessity of these men to dissociate from aspects related to women and transvestites, as Perlongher (2008) argues.

Commercial sex was evident in gay sex tourism, as well as the use of drugs, which played a role in some relations between local men and tourists. Although 
the open sexual activity, drug usage and the existence of commercial sex might be considered by some local people to be "against their values", as one Brazilian male prostitute said, some areas seem to be more permissive to these activities, such as some beaches and clubs. In line with Padilla's (2007) reflections, some local sex workers denied or faked emotional bonds with tourists to preserve their macho self-image. As Padilla (2007) also argues, it was possible to perceive that some tourists seemed to fulfil some psycho-emotional needs of the tourists, such as the search for affection and romance, even though the authenticity of the provided experience from the point of view of some local men may be questioned.

As Miskolci (2013) argues and some tourists also noticed, when local men did not preserve their emotional distance from their clients, they developed a type of homoerotic socialization that opened up an opportunity to a camaraderie with the tourists, who were seen as "machos"-even though they were even called "bitches" during sex-or "brothers". This brings the recognition of the superiority of hegemonic masculinity, although it does not exclude the possibility of sexual involvement among them. The prevalence of hegemonic masculinity-partially because of historical and religious traditions-brought frustration to a tourist who thought that Brazilian men were more liberal and available to have sex with the tourist who was willing to pay for it, in line with Mitchell's (2011) argument.

Sex with tourists, whether explicitly commoditized or not, brings with it the stigma, as indicated by Blanchette \& Da Silva (2011), once it does not conform to social norms. To make them more respectable, some local men negotiate the stigma by attributing it to others-such as transvestites, reinforcing their responsibility by showing that their manly image cannot be confused with "irresponsible boys" and strengthening their masculinity when they try to fit with predominant ideas of "men as providers" when they are paid for the sexual activity, as Padilla (2007) indicates. For some of them, fitting these patterns was a way to access a better life, definitely or occasionally, and escape stigma and disreputability, in projects of social, economic and spatial mobility as described by Carrier-Moisan (2015), especially in relation to tourists potentially interested in long-term relationships.

As the "tourist gaze" is related to the culture and social practices, it is built within a historical context and by multiple groups defined by gender, social class, race and age, together with the development of the media and the means of transportation. This gaze becomes an image with a decisive role in the way the place is perceived, as well as the locals who live in this place (Urry, 2007). The basis of the Rio de Janeiro's image as a tourist destination is its conception as a "paradise" in nature and hospitality, a "Marvellous City" worth seen and visited and, in some sense, "experienced" personally as a faithful representation of the local lifestyle. However, as places are not fixed, the relations between people and places are affectively performed. Nowadays, discussions about Rio's future in the light of growing poverty and violence arise on multiple forums, such as the tour- 
ism industry, government and non-governmental organizations, civil society and the local and global media. The local community's dissatisfaction with Rio's situation makes the city more distant from the "tropical paradise" stereotype on which the city's image was gradually built (Nogueira \& Di Cola, 2018). Even though the notion of "paradise" was not totally destroyed and Rio de Janeiro still attracts a lot of tourists from all around the world, the crisis faced by the city made many people turn to sex tourism as a way to survive or even search for better opportunities in life that cannot be found in the formal sectors of economy.

\section{Conclusion}

Even though sex cannot be indicated as an ever-present phenomenon in gay tourism, sexual possibilities are relevant for some gay travelers (Monterrubio, 2009). The commodification of resources, including the male bodies, may configure them according to the logic of the market and transform the meaning of masculinity and even the gendered nationalist projects in the light of economic exigency (Hodge, 2001). The daydreaming about purchasing power and participation in consumer society is an emotion management technique for sex workers and possibly a way in which they can re-establish their position in their own society and a globalized world. Tourism-related sex labour is one of the spaces in which understandings of racial and sexual identity are represented and exploited toward related aims of material survival, commodity acquisition and consumption. It also becomes a way for the sex worker to become a cosmopolitan subject (Allen, 2007; Mitchell, 2010), as some sex workers in Rio demonstrated.

However, sex tourism cannot be limited to the commodification of bodies. For most local men involved in gay sex with tourists in the case of Rio de Janeiro, prostitution was more than a job, but a lifestyle that follows Rio's gay tourist circuit through repeated scenarios and routines. Gay sex tourism may also involve nonpaid relations between locals and tourists and bring possibilities for diverse feelings, experiences and social practices brought by the multiplicity of personal involvements on the parts involved (Mendoza, 2013). The pathologizing tendencies that insert gay sex tourism simply in the logic of commodification of bodies dehumanized the people involved, which can make one think through entrenched gender biases and moral judgments against them (Allen, 2007). The social construction of gay sex tourism in Rio de Janeiro is based on important dimensions of the body and sexuality which are negotiated between local men and tourists according to personal circumstances, such as the division between heterosexuality and homosexuality, the "North-Atlantic" and "Eurocentric" conceptions of body and sexuality-especially when foreign tourists are considered and the redefinition of the body in the context of a gay lifestyle (Mendoza, 2014).

\section{Conflicts of Interest}

The author declares no conflicts of interest regarding the publication of this paper. 


\section{References}

Allen, J. S. (2007). Means of Desire's Production: Male Sex Labor in Cuba. Identities: Global Studies in Culture and Power, 14, 183-202. https://doi.org/10.1080/10702890601102647

Blanchette, T. G., \& Da Silva, A. P. (2011). Prostitution in Contemporary Rio de Janeiro. In S. Dewey, \& P. Kelley (Eds.), Policing Pleasure: Sex Work, Policy, and the State in Global Perspective (pp. 13-145). New York and London: New York University Press. https://doi.org/10.18574/nyu/9780814785089.003.0010

Brito, J. F., Afonso, R. D., \& Matias, M. (2019). Arquitetura da informação com enfoque semiótico no Guia Gay São Paulo. Brazilian Journal of Information Science: Research Trends, 13, 68-76. https://doi.org/10.36311/1981-1640.2019.v13n1.07.p68

Carr, N., \& Poria, Y. (2010). Introduction: Provision, Marketing, and Consumption of Sex and the Sexual in the Leisure and Tourism Environment. In N. Carr, \& Y. Poria (Eds.), Sex and the Sexual during People's Leisure and Tourism Experiences (pp. 1-13). Cambridge: Cambridge Scholars Publishing.

Carrier-Moisan, M.-E. (2015). "Putting Femininity to Work”: Negotiating Hypersexuality and Respectability in Sex Tourism, Brazil. Sexualities, 18, 499-518. https://doi.org/10.1177/1363460714550902

Clift, S., \& Forrest, S. (1999). Gay Men and Tourism: Destinations and Holiday Motivations. Tourism Management, 20, 615-625. https://doi.org/10.1016/S0261-5177(99)00032-1

Collins, D. (2007). When Sex Work Isn't “Work”: Hospitality, Gay Life, and the Production of Desiring Labor. Tourist Studies, 7, 115-139. https://doi.org/10.1177/1468797607083498

Cox, M. (2001). Gay Holidaymaking: A Study of Tourism and Sexual Culture. Unpublished PhD Thesis, London: University College, UK, University of London.

Herrera, S., \& Scott, D. (2005). We Gotta Get Out of This Place: Leisure Travel among Gay Men Living in Small City. Tourism Review International, 8, 249-262. https://doi.org/10.3727/154427205774791564

Hodge, D. (2001). Colonization of the Cuban Body: The Growth of Male Sex Work in Havana. NACLA Report on the Americas, 34, 20-28. https://doi.org/10.1080/10714839.2001.11722597

Hughes, H. (1997). Holidays and Homosexual Identity. Tourism Management, 18, 3-7. https://doi.org/10.1016/S0261-5177(96)00093-3

Johnston, L. (2001). (Other) Bodies and Tourism Studies. Annals of Tourism Research, 28, 180-201. https://doi.org/10.1016/S0160-7383(00)00012-8

McKercher, B., \& Bauer, T. G. (2003). Conceptual Framework of the Nexus between Tourism, Romance, and Sex. In T. G. Bauer, B. McKercher, \& K. S. Chon (Eds.), Sex and Tourism: Journeys of Romance, Love, and Lust (pp. 3-17). London: Routledge.

Mendoza, C. (2013). Beyond Sex Tourism: Gay Tourists and Male Sex Workers in Puerto Vallarta (Western Mexico). International Journal of Tourism Research, 15, 122-137. https://doi.org/10.1002/jtr.1865

Mendoza, C. (2014). Places, Spaces and Bodies: Male-to-Male Sex Tourism in Puerto Vallarta (Mexico). Athens Journal of Tourism, 1, 175-190. https://doi.org/10.30958/ajt.1-3-1

Miller, J. (2011). Beach Boys or Sexually Exploited Children? Competing Narratives of Sex Tourism and Their Impact on Young Men in Sri Lanka's Informal Tourist Econo- 
my. Crime Law and Social Change, 56, 485-508.

https://doi.org/10.1007/s10611-011-9330-5

Miskolci, R. (2013). Machos e Brothers: Uma etnografia sobre o armário em relações homoeróticas masculinas criadas on-line. Estudos Feministas, 21, 301-324.

https://doi.org/10.1590/S0104-026X2013000100016

Mitchell, G. (2010). Fare Tales and Fairy Tails: How Gay Sex Tourism Is Shaping the Brazilian Dream. Wagadu, 8, 93-114.

Mitchell, G. (2011). TurboConsumersTM in Paradise: Tourism, Civil Rights, and Brazil's Gay Sex Industry. American Ethnologist, 38, 666-682. https://doi.org/10.1111/j.1548-1425.2011.01329.x

Monterrubio, J. C. (2009). Identity and Sex: Concurrent Aspects of Gay Tourism. Tourismos: An International Multidisciplinary Journal of Tourism, 4, 155-167.

Monterrubio, J. C., Hughes, H., Miller, A., \& Mason, P. (2007). Gay Men's Sexual Behaviour in a Holiday Destination. E-Review of Tourism Research, 5, 56-63.

Nogueira, M. A. F., \& Di Cola, L. F. L. L. (2018). From Marvelous City to Olympic City: The Image of Rio de Janeiro as Tourist Destination, Lusophone Journal of Cultural Studies, 5, 103-120.

Oppermann, M. (1999). Sex Tourism. Annals of Tourism Research, 26, 251-266. https://doi.org/10.1016/S0160-7383(98)00081-4

Padilla, M. B. (2007). "Western Union Daddies" and Their Quest for Authenticity: An Ethnographic Study of the Dominican Gay Sex Tourism Industry. Journal of Homosexuality, 53, 241-275. https://doi.org/10.1300/J082v53n01_11

Parker, R. C. (2009). Bodies, Pleasures, and Passions Sexual Culture in Contemporary Brazil. Nashville, TN: Vanderbilt University Press.

Perlongher, N. (2008). O negócio do michê: A prostituição viril em São Paulo. São Paulo: Fundação Perseu Abramo.

Pritchard, A., Morgan, N. J., Sedgley, D., Khan, E., \& Jenkins, A. (2000). Sexuality and Holiday Choices: Conversations with Gay and Lesbian Tourists. Leisure Studies, 19, 267-282. https://doi.org/10.1080/02614360050118832

Reimóndez, M. (2007). Xogos eróticos alén das fronteiras. Grial, 45, 44-49.

Rivers-Moore, M. (2011). Imagining Others: Sex, Race, and Power in Transnational Sex Tourism. ACME: An International E-Journal for Critical Geographies, 10, 392-411.

Ryan, C., \& Kinder, R. (1996). Sex, Tourism and Sex Tourism: Fulfilling Similar Needs? Tourism Management, 17, 507-518. https://doi.org/10.1016/S0261-5177(96)00068-4

Silva, S. S., Cardoso, D. B. P., \& Sousa, B. B. (2018). O papel do marketing no turismo LGBT: Um contributo exploratório no contexto português. Turismo \& Sociedade, 11, 236-260. https://doi.org/10.5380/tes.v11i2.59436

Urry, J. (2007). Mobilities. Cambridge: Polity Press.

Vorobjovas-Pinta, O., \& Hardy, A. (2016). The Evolution of Gay Travel Research. International Journal of Tourism Research, 18, 409-416. https://doi.org/10.1002/jtr.2059

Waitt, G., \& Markwell, K. (2006). Gay Tourism: Culture and Context. New York: Routledge.

Want, P. (2002). Trouble in Paradise: Homophobia and Resistance to Gay Tourism. In S. Clift, M. Luongo, \& C. Callister (Eds.), Gay Tourism: Culture, Identity and Sex (pp. 191-213). London: Continuum. 